\title{
Metallic Materials in Solid Oxide Fuel Cells
}

\author{
Willem Joseph Quadakkers*, Javier Pirón-Abellán, Vladimir Shemet \\ Forschungszentrum Jülich \\ Institute for Materials and Processes in Energy Sytems \\ 52425 Jülich, FRG
}

Received: September 2, 2002; Revised: September 4, 2002

\begin{abstract}
$\mathrm{Fe}-\mathrm{Cr}$ alloys with variations in chromium content and additions of different elements were studied for potential application in intermediate temperature Solid Oxide Fuel Cell (SOFC). Recently, a new type of FeCrMn(Ti/La) based ferritic steels has been developed to be used as construction material for SOFC interconnects. In the present paper, the long term oxidation resistance of this class of steels in both air and simulated anode gas will be discussed and compared with the behaviour of a number of commercial available ferritic steels. Besides, in-situ studies were carried out to characterize the high temperature conductivity of the oxide scales formed under these conditions. Main emphasis will be put on the growth and adherence of the oxide scales formed during exposure, their contact resistance at service temperature as well as their interaction with various perovskite type contact materials. Additionally, parameters and protection methods in respect to the volatilization of chromia based oxide scales will be illustrated.
\end{abstract}

Keywords: Solid Oxide Fuel Cell, interconnect, ferritic steel, high temperature conductivity

\section{Introduction}

Metallic materials for be used as interconnects in SOFCs should fulfil a number of specific requirements ${ }^{1,2}$. Crucial properties of the materials are high oxidation resistance in both air and anode environment, low electrical resistance of the oxide scales formed on the alloy surface as well as good compatibility with the contact materials. Additionally, the value of the coefficient of thermal expansion (CTE) should match with those of the other cell components ${ }^{3}$. These requirements can potentially be achieved with high chromium ferritic steels ${ }^{4}$, however, previous studies ${ }^{5}$ have shown that none of the commercially available ferritic steels seems to possess the suitable combination of properties required for long term reliable cell performance.

One of the most important problems found during stack operation using metallic interconnect materials is the formation of volatile chromium oxides and/or oxy-hydroxides ${ }^{6,7}$ at the cathode side of the cell leading to serious deterioration of the cell performance ${ }^{7}$. Several authors proposed various protective coating types to prevent the deleterious effect of volatile Cr-species ${ }^{8}$.

*e-mail: j.quadakkers@fz-juelich.de

Presented at the International Symposium on High Temperature Corrosion in Energy Related Systems, Angra dos Reis - RJ, September 2002.
Recently, a new class of FeCrMn(La/Ti) ferritic steels (see Table 1) has been developed to be used as construction materials for SOFC interconnects ${ }^{4,9}$. The steels contain a $\mathrm{Cr}$ content in the range $20-24 \mathrm{wt} . \%$, a Mn content of a few tenths of a percent whereas the additions of $\mathrm{La}$ and $\mathrm{Ti}$ are in the range of a few hundred ppm. In the present study, the long term oxidation resistance of some of these $\mathrm{FeCrMn}(\mathrm{La} / \mathrm{Ti})$ steels in both air and simulated anode gas has been studied and compared with the behaviour of a number of commercially available ferritic steels. Main emphasis was put on the growth and adherence of the oxide scales formed during exposure, their contact resistance at service temperature as well as their interaction with various perovskite type contact materials.

\section{Experimental details}

The model ferritic $\mathrm{Cr}$ steels with variation in $\mathrm{Mn}$, Ti and La content were manufactured by Krupp/Thyssen NIROSTA (KTN). The main features of the various studied alloy types are given in Table 1. The studied commercial alloys, supplied by Hitachi metals, KTN and Rolled Alloys, are listed 
in Table 2. For oxidation studies, samples of dimensions $20 \times 10 \times 2 \mathrm{~mm}$ were cut from the prevailing semi-finished products, ground to 1200 grit surface finish and finally cleaned in acetone. Discontinuous oxidation tests were carried out at $800{ }^{\circ} \mathrm{C}$ in air and in a simulated anode gas (Ar$4 \% \mathrm{H}_{2}-2 \% \mathrm{H}_{2} \mathrm{O}$ ). For weight measurements the exposures were interrupted every $250 \mathrm{~h}$. For more detailed analysis of the oxidation kinetics, isothermal oxidation tests using a SETARAM thermobalance were carried out. The oxide scales formed during oxidation in the various atmospheres were studied by light optical microscopy, scanning electron

Table 1. Studied model and semi-commercial $\mathrm{FeCrMn}(\mathrm{La} / \mathrm{Ti})$ alloys.

\begin{tabular}{ccc}
\hline $\begin{array}{c}\text { Steels } \\
\text { designation }\end{array}$ & Batches & Major features \\
\hline JS-1 & HNA, HMZ & high Mn, Ti, La \\
JS-2 & HXV & high Mn, low Ti, La \\
JS-3 & HUF, JDA, & Low Mn, Ti, La \\
& JEW, JEX & \\
\hline
\end{tabular}

microscopy (SEM) with energy dispersive X-ray analysis (EDX) and X-ray diffraction (XRD). The contact resistances of the oxide scales were measured using a conventional four point method. For these studies, samples of $10 \times 10 \times 2 \mathrm{~mm}$ were ground to 1200 grit surface finish and finally pre-oxidized for $100 \mathrm{~h}$ at $800^{\circ} \mathrm{C}$ in air. Subsequently, a layer of Ptpaste was applied to both oxidized surfaces. For the electrical connection a Pt-mesh was used. The contact resistance was monitored in-situ during $500 \mathrm{~h}$ exposure at $800{ }^{\circ} \mathrm{C}$ in air.

For studies concerning the compatibility of the steels with contact layers, samples of $20 \times 10 \times 2 \mathrm{~mm}$ were ground to 1200 grit surface finish and pre-oxidized for $100 \mathrm{~h}$ at $800{ }^{\circ} \mathrm{C}$ in air. Subsequently, various La-based perovskite type contact pastes ${ }^{10}$ were applied on top of one side of the samples which were then exposed for $1000 \mathrm{~h}$ at $800{ }^{\circ} \mathrm{C}$ in air.

\section{Results and discussions}

Figure 1 shows the oxidation behaviour under cyclic oxidation conditions for several FeCrMn model alloys with and without $\mathrm{Ti}$ and La additions compared with the behav-

Table 2. Chemical compositions of the studied commercial ferritic steels (Mass.- \%).

\begin{tabular}{cccccccc}
\hline Alloy designation & $\mathrm{Fe}$ & $\mathrm{Cr}$ & $\mathrm{Mn}$ & $\mathrm{Ti}$ & $\mathrm{Al}$ & $\mathrm{Ni}$ & $\mathrm{Si}$ \\
\hline 1.4509 & Bal. & 18 & 0.38 & 0.12 & 0.03 & 0.12 & 0.7 \\
446 & Bal. & 25 & 0.5 & 0.05 & - & - & 0.29 \\
$1.4016-3 \mathrm{C}$ & Bal. & 16 & 0.3 & - & - & 0.26 & 0.41 \\
1.4742 & Bal. & 17 & 0.31 & 0.01 & 1.04 & 0.18 & 0.93 \\
ZMG232 & Bal. & 22 & 0.45 & - & 0.19 & - & 0.35 \\
\hline
\end{tabular}

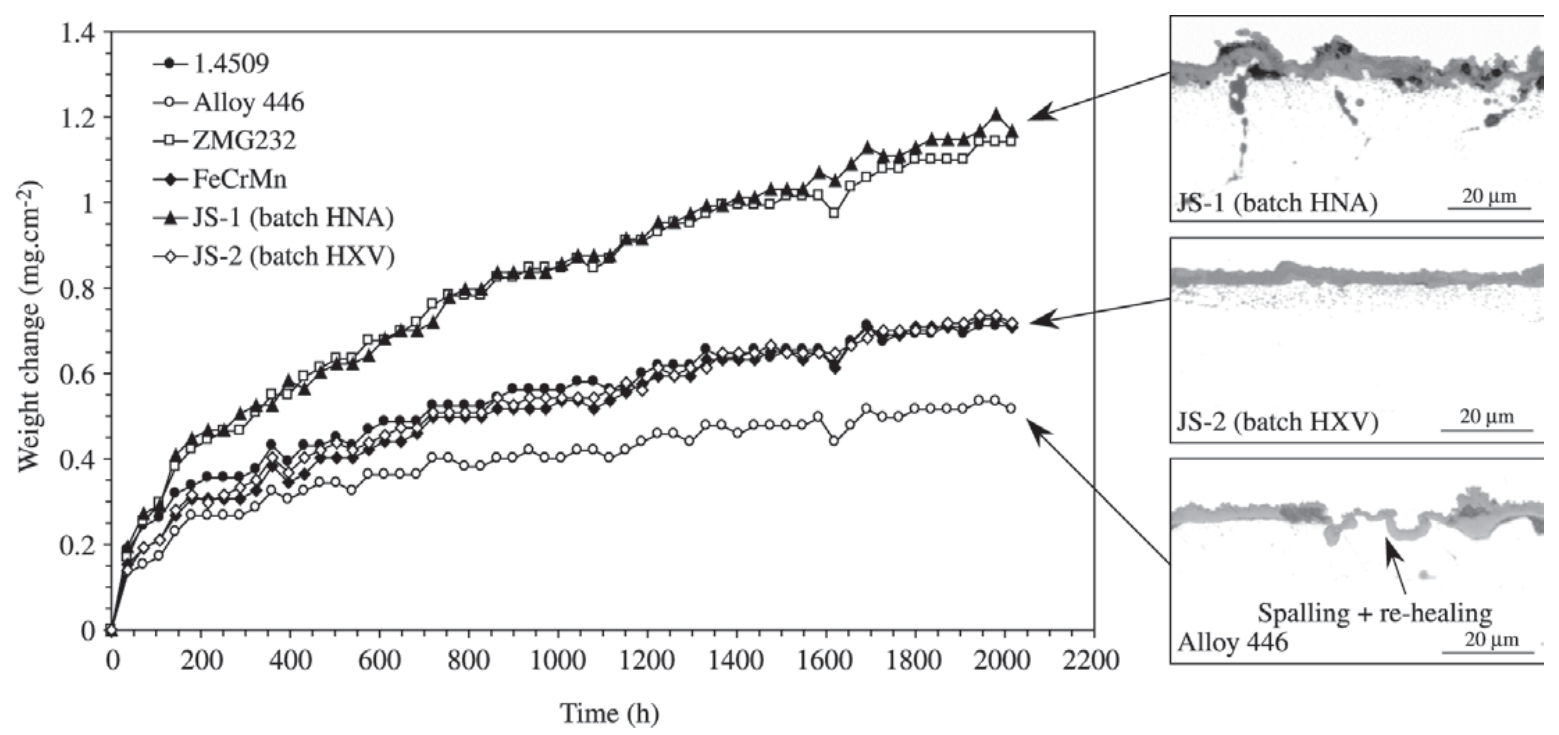

Figure 1. Oxidation behaviour under cyclic conditions of several commercial and model ferritic steels at $800{ }^{\circ} \mathrm{C}$ in air. 


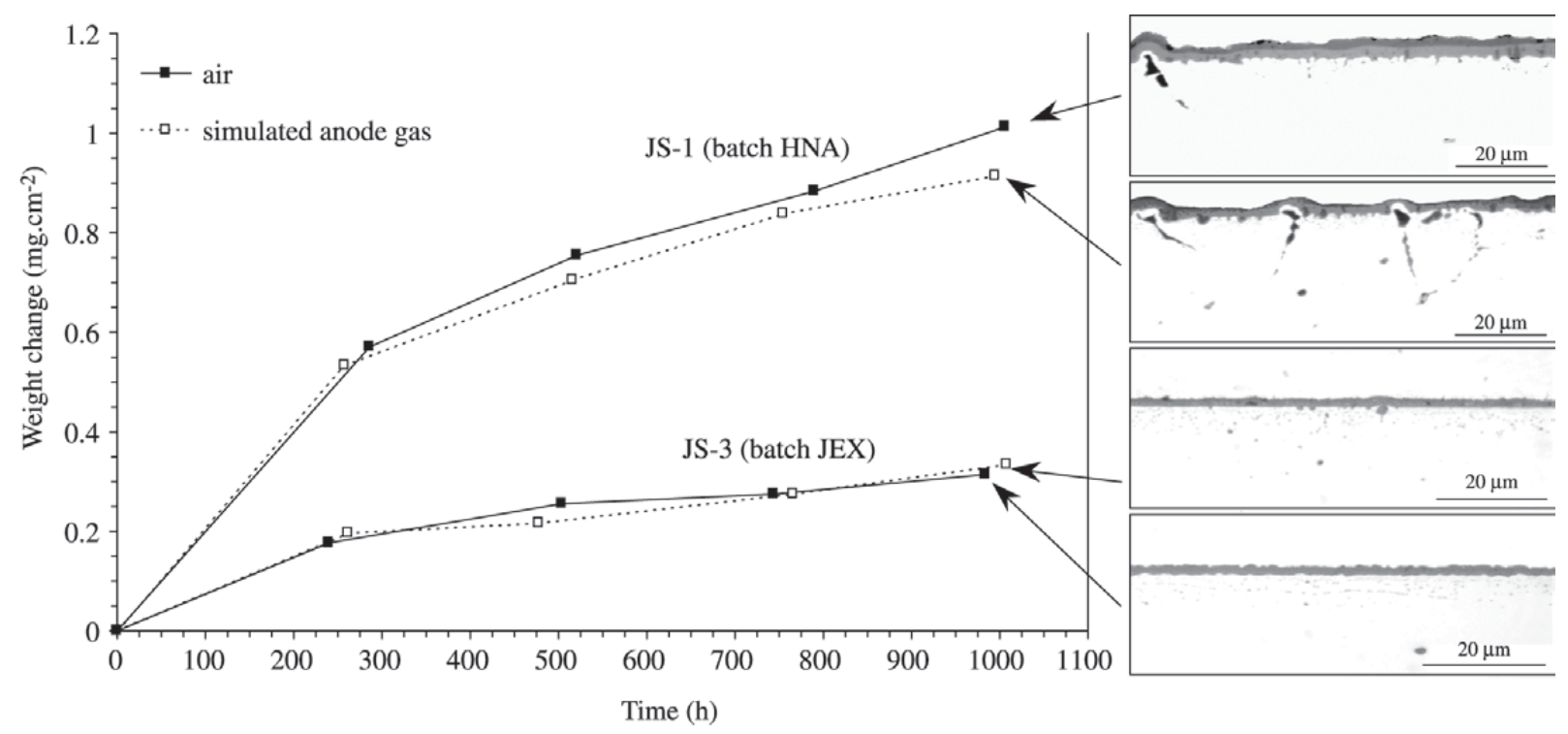

Figure 2. Oxidation behaviour of selected model ferritic steels at $800{ }^{\circ} \mathrm{C}$ in air and $\mathrm{Ar}-4 \% \mathrm{H}_{2}-2 \% \mathrm{H}_{2} \mathrm{O}$.

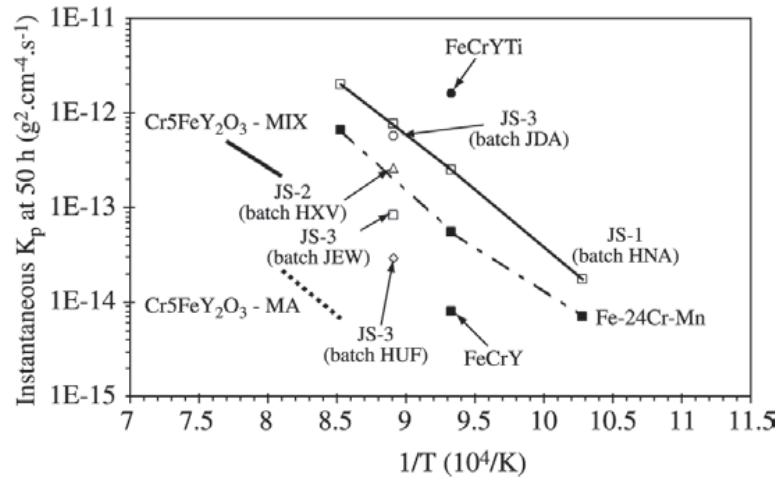

Figure 3. Instantaneous $\mathrm{K}_{\mathrm{p}}$ values at $50 \mathrm{~h}$ as function of temperature during isothermal oxidation in $\mathrm{Ar}-20 \% \mathrm{O}_{2}$ compared with values for the ODS alloy $\mathrm{Cr}_{5} \mathrm{FeY}_{2} \mathrm{O}_{3}$.

iour of some of the most promising commercial ferritic steels. The JS-1 alloy (batch HNA) and the commercial alloy ZGM232 show the highest weight changes mainly due to the extensive internal oxides formed beneath the scale. The other studied alloys show similar oxide scale growth rates because either no internal oxides are present at all or they appear in form of very fine internal precipitates. The two commercial alloys 1.4509 and 446 exhibited substantial scale spallation during the oxidation test but the chromium concentration is still sufficiently high to re-form the chromia based scale.

Figure 2 shows the oxidation behaviour of alloys JS-1 and JS-3 (batches HNA and JEX) oxidized in both air and simulated anode gas. A general tendency is that the oxide scales formed in anode gas are slightly thinner than those formed in air. As has previously been reported for Cr-based alloys ${ }^{11}$, for all studied alloys the scales formed in the anode gas generally possess better adherence than those formed in air or oxygen.

Figure 3 shows the instantaneous $\mathrm{K}_{\mathrm{p}}$-values at $50 \mathrm{~h}$ determined during isothermal oxidation in $\mathrm{Ar}-\mathrm{O}_{2}$ for a number of $\mathrm{FeCr}$ alloys with and without $\mathrm{Mn}$, Ti and/or La additions in comparison with a number of other SOFC relevant alloys as function of the reciprocal temperature. The addition of $\mathrm{Ti}$ to the $\mathrm{FeCr} / \mathrm{Y}$ alloy leads to a substantial increase in the oxidation rate. The enhancement increases with increasing Ti content, in agreement with previous findings related to the behaviour of NiCr-based alloys in steam reforming gas ${ }^{12}$. Comparing the alloys FeCrMn and JS-1 (batch HNA) it is clear that in the entire range of temperatures studied, only minor changes in the Mn, La and Ti contents can substantially affect the oxidation rate. Based on these findings, suitable oxidation resistance of the ferritic steels requires adequate addition and careful control of these elements in the alloy. By optimum additions of the oxygen active elements, oxidation rates can be achieved which are similar to those of chromium based ODS alloys, which have frequently been proposed as interconnect material for high temperature $\mathrm{SOFCs}^{13,14}$.

The electrical resistances of the oxides scales formed on different $\mathrm{FeCrMn}(\mathrm{La} / \mathrm{Ti})$ alloys during exposure at $800{ }^{\circ} \mathrm{C}$ are shown in Fig. 4. The results are compared with data 
obtained for a number of commercial alloys, i.e., 1.4742 (X10CrAl18), 1.4509 (X2CrTiNb18), alloy 446 and alloy ZGM232. The values obtained for alloys 1.4509, 446 and ZMG232 showed a very wide scatter range, although on all three materials, the oxides formed mainly consist of a duplex $\mathrm{MnCr}_{2} \mathrm{O}_{4} / \mathrm{Cr}_{2} \mathrm{O}_{3}$ scale.

The highest values of approximately $20 \Omega \mathrm{cm}^{2}$ were obtained for the commercial alloy 1.4742 which has in some cases been considered as a potential candidate to be used as interconnect in intermediate temperature SOFCs.

These high values can be explained by the fact that this alloy, depending on the exact alloy composition and surface treatment, in some cases tends to form a very protective alumina scale ${ }^{5}$, which, however, possesses a very poor electrical conductivity. In contrast, the new JS-3 alloys (batches JDA, JEW, and JEX) show very low contact resistance values of approximately $10 \mathrm{~m} \Omega \mathrm{cm}^{2}$, i.e., values which are two to three orders of magnitude smaller than those of most com-

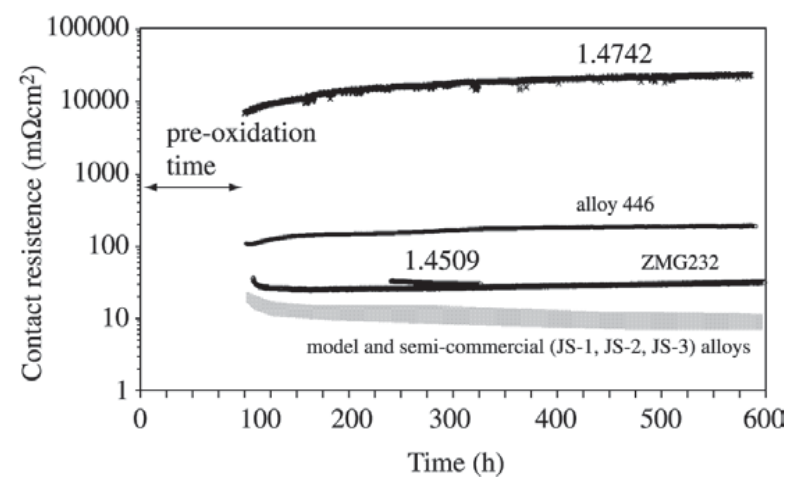

Figure 4. Contact resistance of commercial ferritic steels and $\mathrm{FeCrMn}\left(\mathrm{La} / \mathrm{Ti}\right.$ ) alloys (JS-1, JS-2, JS-3) at $800{ }^{\circ} \mathrm{C}$ in air.

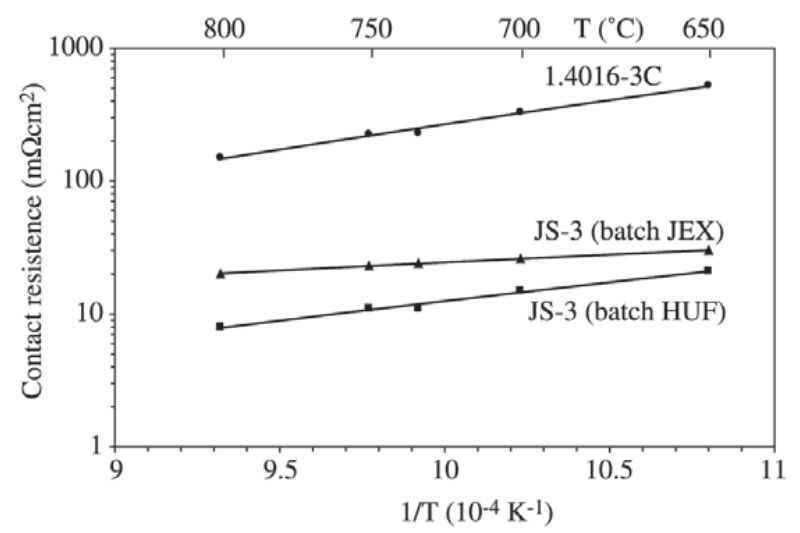

Figure 5. Contact resistance of the oxide scales formed on various ferritic steels as function of time. mercial alloys. In Fig. 5 the contact resistances as function of time for various JS-3 alloys compared with the commercial alloy 1.4016-3C are plotted. The contact resistance values for 1.4016-3C are higher than those of newly developed JS-3 alloys and increase with decreasing temperature. The temperature dependence was more pronounced for the commercial alloy than for the JS-3 alloys. At lower temperatures the JS-3 alloys show relative higher conductivity compared to the commercial 1.4016-3C alloy.

In a planar cell configuration the connection between the interconnect and the cathode material is frequently achieved by using a contact layer which compensates geometrical irregularities of the cathode and/or interconnect surface $^{5}$. Because the contact layers have to possess a high electronic conductivity, they commonly consist of La-based perovskites ${ }^{15}$. In the present study, selected contact pastes, $\mathrm{La}(\mathrm{Sr}) \mathrm{MnO}_{3}, \mathrm{LaCoO}_{3}$ and $\mathrm{LaCoMnO}_{3}$, were applied on top of pre-oxidized sample surfaces of a selected JS-1 alloy (batch HMZ) in form of a slurry coating. The coated samples were then oxidized for $1000 \mathrm{~h}$ at $800{ }^{\circ} \mathrm{C}$ in air. Subsequently, the alloy/coating interaction was studied by metallographic cross sections. The results in Fig. 6 illustrate that the alloy/perovskite interaction strongly depends on the contact layer composition. In case of $\mathrm{LaCoMnO}_{3}$ a thin interaction layer is formed and the formation of the spinel $\mathrm{MnCr}_{2} \mathrm{O}_{4}$ was suppressed. When $\mathrm{La}(\mathrm{Sr}) \mathrm{MnO}_{3}$ is used, the formation of this spinel-type takes place at the interface with the contact paste. However, some chromium was detected on the surface of the contact layer. The use of $\mathrm{LaCoO}_{3}$ as contacting material might reduce the chromium diffusion through the contact paste because no enrichment of this element was observed. This effect may be due to the formation of a dense interaction layer which consists of a mixture of spinel and perovskite compounds which are virtually free of $\mathrm{Cr}$.

\section{Conclusions}

Commercial high $\mathrm{Cr}$ ferritic steels as interconnect material have large drawbacks because the materials tend to exhibit substantial scale spallation during long term oxidation, especially under cyclic oxidation conditions. Besides, the formed oxide scales frequently exhibit high electrical resistances. These effects are mainly related to a poor control of the oxygen active minor alloy constituents. For these reasons, new alloys of the type $\mathrm{FeCrMn}(\mathrm{La} / \mathrm{Ti})$ were developed to be used as interconnect materials for SOFCs. These alloys form oxide layers with low growth rates being constituted by a duplex $\mathrm{MnCr}_{2} \mathrm{O}_{4} / \mathrm{Cr}_{2} \mathrm{O}_{3}$ scale. The formation of the external spinel layer considerably reduces the chromium evaporation ${ }^{8}$. Also, it has been demonstrated that this type of scale has a low contact resistance, i.e., two to three orders of magnitude lower than that of alumina-rich scales 

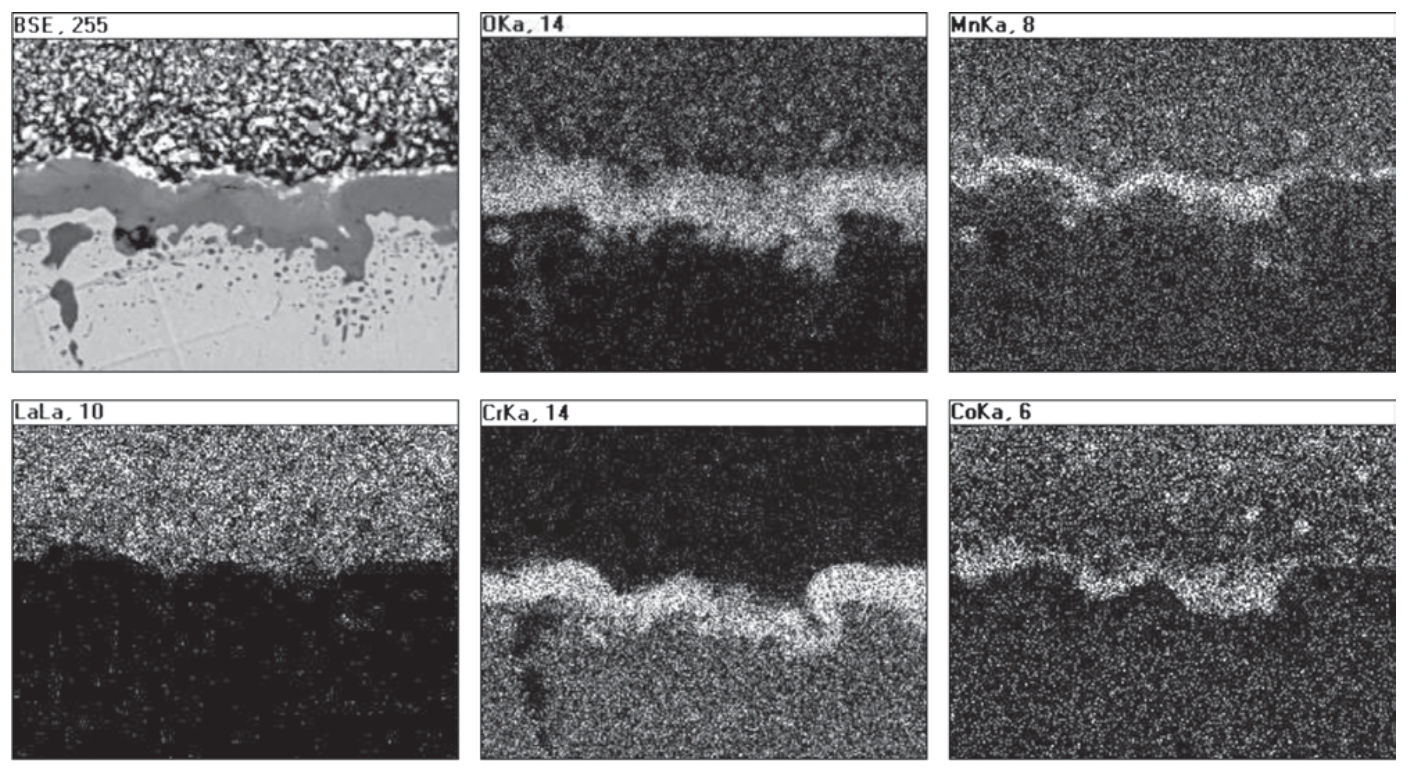

a)
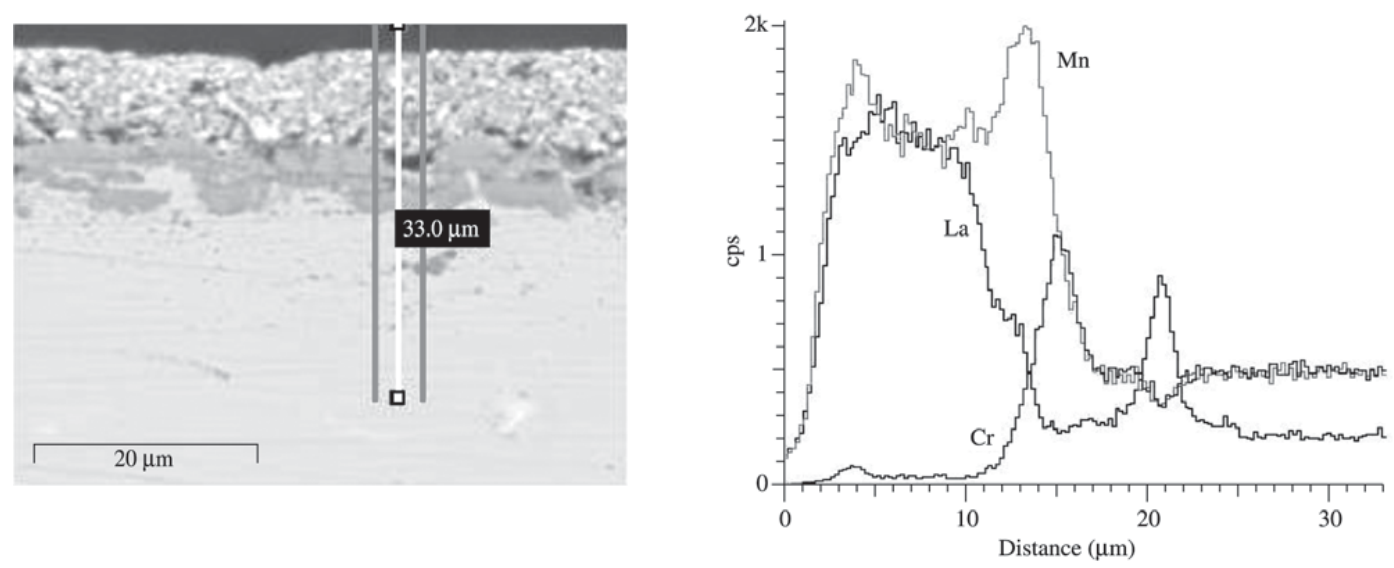

b)
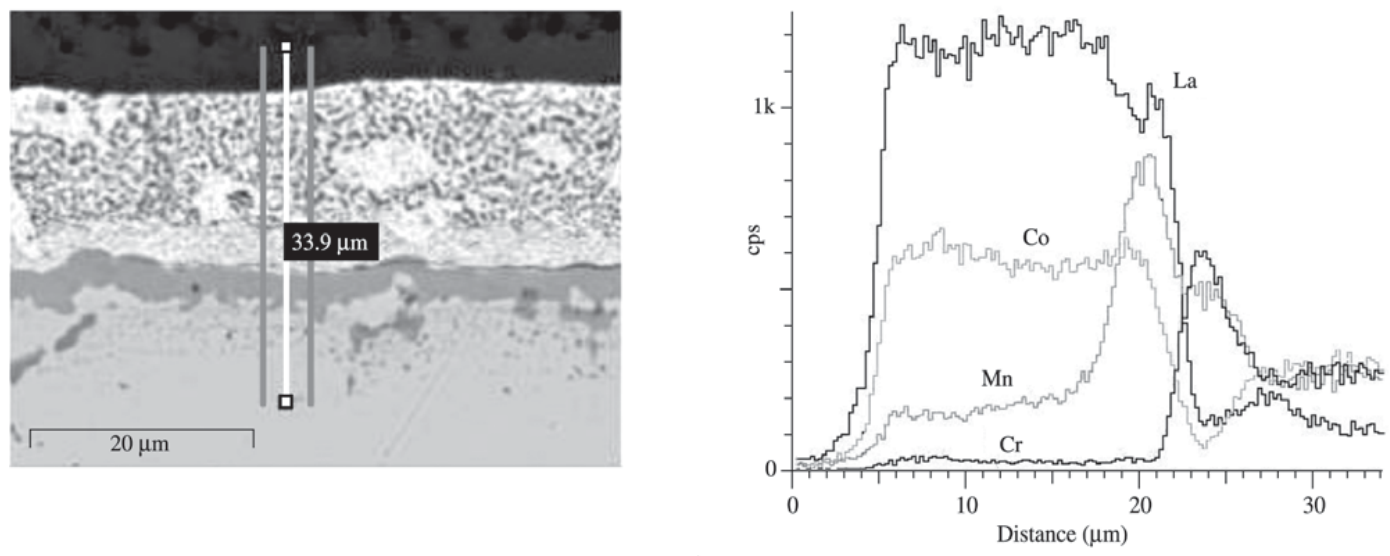

c)

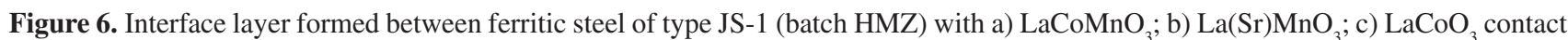
layer during $1000 \mathrm{~h}$ exposure at $800{ }^{\circ} \mathrm{C}$ in air, showing metallographic cross section, element mappings and EDX line profiles. 
frequently formed on commercial ferritic steels. Besides, the combination of these new steels with suitable perovskitetype contact layers allows to achieve interaction layers with low electronic resistance ${ }^{10}$ which even further reduce the formation of volatile $\mathrm{Cr}$ species.

\section{Acknowledgement}

The authors are grateful to their colleagues Mr. Mahnke and Mr. Cosler for carrying out the oxidation experiments, Mr. Schmidt for preparing the contact layers, Mr. Gutzeit for the metallographic investigations and Dr. Wessel for the SEM/EDX analyses.

\section{References}

1. Greiner, H.; Grögler, T.; Köck, W.; Singer, R.F. Proc. $4^{\text {th }}$ International Symposium Solid Oxide Fuel Cell (SOFC IV), Yokohama, Japan, 18- 23 June 1995, Edts. Dokiya, M.; Yamamoto, O.; Tagawa, H.; Singhal, S. The Electrochem. Soc., Pennington, NJ, USA, p. 841-849, 1995.

2. Badwal, S.P.S.; Deller, R.; Foger, K.; Ramprakash, Y.; Zhang, J.P. Solid State Ionics, v. 99, p. 297-310, 1997.

3. Malkow, Th.; Crone, U.v.d.; Laptev, A.M.; Koppitz, T.; Breuer, U.; Quadakkers, W.J. Proc. of the $5^{\text {th }}$ International Symposium on Solid Oxide Fuel Cells (SOFC-V), Aachen, Germany, 2-5 June 1997, Ed. Stimming, U.; Singhal, S.C.; Tagawa, H.; Lehert, W. Electrochemical, Society Inc., Penn., p. 1244-1252, 1997.

4. Quadakkers, W.J.; Malkow, Th.; Pirón-Abellán, J.; Flesch, U.; Shemet, V.; Singheiser, L. $4^{\text {th }}$ European SOFC Forum, 10-14 July 2000, Lucerne, CH, Proceedings, Edt. A. McEvoy, p. 827-836, 2000.

5. Malkow, Th.; Quadakkers, W.J.; Singheiser, L.; Nickel, H. Report Forschungszentrum Jülich, Jül-3589, ISSN 0944-2952, October, 1998.

6. Quadakkers, W.J.; Greiner, H.; Köck, W.; Buchkermer, H.P.; Hilpert, K.; Stöver, D. $2^{\text {nd }}$ European SOFC Forum,
6-10 May 1996, Oslo, Norway, Ed. Thorstensen, B., p. 297-306, 1996.

7. Jiang, S.P.; Zhang, J.P.; Apateanu, L.; Foger, K. Journal of the Electrochemical Society 147, p. 4013-4022, 2000.

8. Gindorf, C.; Singheiser, L.; Hilpert, K.; Schroeder, M.; Martin, M.; Greiner, H.; Richter, F. Proc. $6^{\text {th }}$ International Symposium on Solid Oxide Fuel Cells (SOFC-VI), Honolulu, Hawaii, 17-22 October 1999, Edt. Singhal, S.C.; Dokiya, M. The Electrochem. Soc., Pennington NJ, USA, p. 812-821, 1999.

9. Pirón-Abellán, J.; Shemet, V.; Tietz, F.; Singheiser, L.; Quadakkers, W.J. $7^{\text {th }}$ International, Symposium on Solid Oxide Fuel Cell (SOFC-VII), EPOCHAL, Tsukuba, Japan, 3-8 June 2001, Proceedings The Electrochem. Soc., Pennington, NJ, USA, p. 811-819, 2001.

10. Teller, O.; Meulenberg, W.A.; Tietz, F.; Wessel, E.; Quadakkers, W.J. Proc. $7^{\text {th }}$ International, Symposium on Solid Oxide Fuel Cells (SOFC-VII), EPOCHAL, Tsukuba, Japan, 3-8 June, 2001, Proceedings The Electrochem. Soc., Pennington, NJ, USA, p. 895-903, 2001.

11. Quadakkers, W.J.; Norton, J.F.; Canetoli, S.; Schuster, K.; Gil, A. 3rd International conference on 'Microscopy of Oxidation' Cambridge, September 16-18th, 1996, Proceedings, The Institute of Materials, Edts. S.B. Newcomb, J. A Little, p. 609- 619, 1997.

12. Ennis, P.J.; Quadakkers, W.J. Conference High Temperature Alloys - Their Exploitable Potential, 15-17 Oct. 1985, Petten, NL, Proceedings, Elsevier London, p. 465474, 1988.

13. Crone, U.v.d.; Hänsel, M.; Quadakkers, W.J.; Vaßen, R. Fresenius Journal of Analytical Chemistry, v. 358, p. 230232, 1997.

14. Quadakkers, W.J.; Hänsel, M.; Rieck, T. Materials and Corrosion, v. 49, p. 252-257, 1998.

15. Quadakkers, W.J.; Greiner, H.; Hänsel, M.; Pattanaik, A.; Khanna, A.S.; Malléner, W. Solid State Ionics, v. 91, p. 55-67, 1996. 